Since the late 1980s, Israel has been undergoing a profound transformation, characterized by reconciliation with its Arab neighbours and attempts to reintegrate into the regional economy, a transition from a militarized economy to open markets, and a decline of the collectivist ethos in favour of liberalism and free enterprise. This transition, we argue, is part of a world-wide shift from the 'depth' to the 'breadth' of accumulation and the parallel globalization of ownership. In order to survive, the large Israeli corporations must substitute outward expansion for the old protectionism of a militarized economy, and give up domestic control in return for global alliances.

\title{
From War Profits to Peace Dividends: The New Political Economy of Israel
}

\section{by Jonathan Nitzan and Shimshon Bichler}

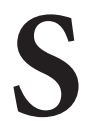

INCE THE END OF THE 1980S, Israel appears to have entered a fundamental transformation. From a militarized economy characterized by large government deficits, heavy dependency on the US and intense stagflation, there is now a decisive move toward peace and regional integration, economic growth and declining military spending. These developments come amidst a deep ideological and cultural change sanctioning the centrist/liberal world view of the Labour and Meretz parties. Increasingly, there are calls not only for a more open foreign policy but for an entirely different regime based on political democratization, economic liberalization and a dismantling of the welfare state. The Zionist-collectivist ethos seems to have finally given way to the universal creed of business enterprise.

The purpose of the article is to offer an alternative analytical framework for understanding this long-term transformation. First, we argue against the conventional separation between the 'political system' and the 'economic 
system.' This method has been popular among Israeli scholars but its analytical value is open to doubt. Second, instead of the common aggregate/statist approach, we take the disaggregate route of political economy, accentuating the historical role played by key power groups. And, finally, rather than focus merely on domestic considerations, we claim that both the earlier military economy as well as the current trajectory into 'peace markets' are part of broader global developments, particularly the internationalization of business institutions and the changing nature of the capitalist nation state.

In our opinion, the sharp 'U-Turn' in Israeli history is intimately linked to the changing nature of capital accumulation and corporate concentration, both in Israel and in the US. For the large core firms at the centre of the economy, which we view as principal actors in this process, accumulation and concentration are two side of the same process. With the evolution of modern capitalism, the leading firms are increasingly driven not to maximize their profits but rather to 'beat the average.' Specifically, they seek to achieve a differential rate of accumulation - that is, to exceed the average rate of return in the economy. Since a differential growth in profits implies control over a growing share of the aggregate capitalized assets, for these firms the goal of accumulation means a quest for rising corporate concentration. ${ }^{1}$

Differential accumulation can be achieved in two ways. One is to raise the 'depth of accumulation' by maintaining profit margins above the economy's average. The other is to focus on the 'breadth of accumulation' by expanding market share. Although the two methods are not mutually exclusive, economic conditions which are conducive to one often undermine the other. During the 1970s and much of the 1980s, Israel and the US were both characterized by a politicaleconomic structure in which a combination of corporate concentration and stunted growth gave rise to 'military Keynesianism'-much along the lines outlined by Luxemburg, Hilferding, and the Monopoly-Capital school of Baran and Sweezy. Under these circumstances, corporate concentration is typically maintained and enhanced by expanding the depth of accumulation: the large corporations try to raise their profit margins above those of smaller periphery firms and the ensuing 'profit competition' often culminates in a stagflationary spiral (Nitzan 1992). However, since the mid 1980s, and particularly 
with the disintegration of the Soviet Union and the opening to business of China, India and South-East Asia, the large firms both in Israel and in the US have changed gear, moving toward an alternative model of peaceful expansion. This pattern of accumulation was anticipated and described by Schumpeter and by Kautsky (who even labelled it as 'ultra imperialism'). Under this latter regime, the core corporations advance their differential position by expanding the breadth of accumulation: instead of competing over profit margins, the differential increase in profits comes from a rapid intrusion into new markets and the consequent expansion of market share. This mode of differential accumulation is accompanied by falling military spending, disinflation and revived growth.

The focus on the process of accumulation sheds new light on the history of Israel. The first section of the article examines some of the fundamental assumptions underlying the Israeli political and economic literature of the past three decades. According to this literature, Israel represents a 'special case'but then, that is so only because most writers have chosen to ignore the process of accumulation. If the latter is put at the centre of analysis, Israel's political-economic history no longer seems unique. The second section examines briefly the 'military bias' of mature capitalist economies, with specific emphasis on the US. In the third section, we argue that until the late 1980s, the Israeli military bias has been similarly affected by pressures emanating from growing corporate concentration, as well as by the country's role in the superpower confrontation. These consideration could then help explain the current peace process. In the fourth section, we claim that fundamental changes in the global pattern of accumulation have left the Israeli elite (and many of the Arab ones) with little choice but to accept the imperative of open boarders and global ownership. In a certain sense, the current enthusiasm for peace is similar to the earlier obsession with national security: they both serve the quest for differential accumulation.

\section{THEORETICAL BACKGROUND}

The Israeli literature dealing with the economics and politics of war and peace suffers from several related shortcomings: (1) An emphasis on the 'statist' frame of reference, (2) a view that 
the historical development of Israel was predetermined by 'unique' circumstances, and (3) a belief that as a consequence of these circumstances, Israel has developed into a 'special case' of classless society; a society in which the process of capital accumulation and the role of elites could be safely ignored. We deal with these issues in turn.

The 'statist' or 'state-centred' approach grew increasingly fashionable since the 1970s (Tilly 1975; Krasner 1978; and Skocpol 1985; for the Israeli case, see Migdal 1989 and Barnett 1992). The basic unit of analysis here is the nation state, whose actions are dominated by an amorphous group of 'centraldecision makers,' 'state officials,' and 'rulemakers.' This group is supposedly driven by the national interest and seeks to achieve broad macroeconomic goals such as growth and a favourable balance of payments, or macropolitical aims like military prowess and social stability (for instance Arian 1989). These broad ends are emphasized for their universality and perceived as independent of particular interests.

The aims of the state are formulated in aggregate terms-a habit of thinking which emerged and consolidated with the Keynesian paradigm (Tsuru 1968). Society is divided into two systems of 'economics' and 'politics.' In the Israeli context, it is assumed that the economic system would guarantee universal welfare-that is, if only it were allowed to function 'efficiently.' The political system often undermines that efficiency when it seeks to achieve additional goals such as 'national security' but fails to find the optimal rate of substitution between security and economic growth along the nation's productionpossibilities frontier. With its foundations deeply embedded in the neoclassical paradigm, the focus on 'aggregate welfare' enables the writer to remain within the boundaries of the national consensus (Robinson 1962: 117-18), and has driven many Israeli academics to accept the supremacy of the political echelon.

Thus, Berglas (1970) asserts that 'the central problem of the economic policy in Israel is choosing the right point on the curve [production possibilities frontier],' yet he immediately adds that this choice must be determined by 'security considerations' which are 'beyond the domain of this article' (p.194). That particular article was written at a sensitive period, right at the end of the Israel-Egyptian war of attrition-though time has done little to change the author's 
basic presumption. Thirteen years later, after the 1982 Israeli entanglement in Lebanon, Berglas still claims that 'the purpose of military expenditures [in Israel] is both to deter potential enemies from starting a war and to achieve superiority once a war has started,' and that 'it is thus difficult even in retrospect to assess the success or failure of a military expenditure program' (Berglas 1983: 16). Likewise, Hasid and Lesser, while working as senior economists at the Ministry of Security, asserted that although 'Israeli society is democratic, free, peace seeking and striving for standard and quality of living much like the progressive western states, Israel is coerced into a permanent state of war.' In this context, they explained, 'the allocation of resources for security involves national risks which are very difficult to assess in any objective way' (1981: 243). These assertions may be all true of course, but then if all the crucial historical decisions are determined by autonomous state officials, uncompromising Arab regimes and ideological inclinations, why the scientific pretensions of rational 'economism'?

The total subjugation of the economy to the state is manifest in Sadan (1985: 119), an economics professor and general manager of the finance ministry at the time: 'In Israel,' he asserted, 'economic goals arise naturally from the general goal of the survival of the state.' Indeed, 'planning for survival includes economic growth, and even when this is not an objective in and of itself, it is a means for making possible the establishment of the defense system required for future wars.' The Hobbesian view has been so thoroughly accepted in Israeli political literature that some researchers have decided to skip the analysis altogether and turn directly to policy implications. Klieman (1992), for example, still has little doubt about value of Israeli militarism. For him, the main issue is the benefit for the 'state,' and the principal question is, 'how could Israel best respond to mounting challenges in the global weapon market and how should it preserve its position and competitive advantage?' (p.326) His answer is that Israel '...should continue with its tradition of domestic dexterity and external cunning'! (p.336).

The substitution of advice for serious research is typical of an academic community captured by rigid consensus. Perhaps the clearest expression of this consensus is the repeated useoften unconscious - of terms such as 'we,' 'us' and 'ours,' 
usually coupled with a need for 'sacrifice' (on the concept of 'we,' see Barnet 1972: 7). Aharoni (1969), for example, describes how 'we are required, and justly so, to demonstrate resilience and hold out against political and economic pressures,' while 'our young are called for a long reserve service and bloodletting' (p.157). Although Aharoni hinted that the Labour government of Golda Meir should re-evaluate its priorities, he was also quick to add that this was 'not to doubt the need to devote whatever is necessary in order to assure our very survival' (p.160). And once defense cuts are ruled out, an economist can step in to announce that 'if we want to enjoy this kind of growth in the future, we must begin immediately by rapidly reducing the standard of living' (Berglas 1970: 195).

The adoption of the state-centred approach by Israeli academics was greatly facilitated by the view of Israel as a sui generis case. The first reason is exogenous. Unlike many other democracies, we are told, 'Israel's very survival has been threatened for many years' so 'one cannot apply the concept of military-industrial complex to this Western-style democracy in the sense of a conspiracy by heads of the political, defense and economic establishment solely for the sake of furthering their own interests (Mintz 1984: 104). Following a similar vain, Peri (1983: 1) writes that 'the all-encompassing nature of war in Israel and the centrality of security to national existence have created a situation whereby numerous spheres, which in parliamentary democracies are considered "civil", fall within the security ambit and are enveloped in secrecy.' And so, 'Beyond the ideological and political disagreements prevailing in the Israeli public,' write Horowitz and Lissak (1988: 28), 'there was always a broad consensus regarding the threat for survival embedded in the Israeli-Arab dispute' (see also Horowitz and Lissak 1989, ch.6). The consequence was that Israel became a unique case. 'Unfortunately,' writes Ben Dor (1977: 431), 'in the current state of the theoretical literature, Israel constitutes such an exceptional case of a "nation in arms" (a "barrack democracy"), that it is almost impossible to compare it to any other similar case.' And, 'In spite of the many references to Israel and the IDF in comparative works on civil-military relations, none of the existing conceptual frameworks in the field appear fully applicable to the case of Israel' (Horowitz 1982: 96). 
The second reason for the uniqueness of Israel stems from its own 'primordial sin': the East-European founding fathers instituted an authoritarian 'socialist' culture which, according to the overwhelming majority of Israeli social scientists, has since lied at the heart of the 'Israeli malaise.' Beginning in the 1920s, the political system has seized control of the economy, first through the Labour party and the Histadrut (federation of labour unions), which then transferred their power to the government of the newly-formed state. The result was the institutionalization of an authoritarian/statist culture. Shapiro (1975: 207-8), for example, believes that contrary to the basic individualistic-liberal principles of western society, Israel has failed to maintain the necessary separation between economics and politics and allowed the public-political domain to impinge upon the private-economic sphere (also Shapiro 1977; Arian 1989; Aharoni 1991). The consequences for Israeli society were detrimental. The petrifying of political dominance since the British Mandate era has created grave 'distortions,' mostly associated with the evils a 'socialistic tradition' and excessive 'government intervention' (Halevi and Klinov-Malul 1968: 4). From the new-right perspective of Sharkansky, 'the predominance of the government in Israel's economy makes it the most socialist country outside the Eastern Bloc' and so 'It is Israel's fate to suffer the worst from the centrally controlled east and the democratic west' (1987: 5). The model, then, is simple: a socialist tradition inevitably gives rise to a statist bureaucracy, which undermines the vitality of private enterprise and brings chronic stagnation.

Clearly, Israel is like no other capitalist society. Its history is the result of 'the trilateral relationship between the settlement movement, the pioneering elite which exercised its control through the political parties and the bureaucratic stratum which recognized its hegemony' (Shapiro 1984: 45). It is 'a party state in which almost everything is determined by political parties' (Goldberg 1992: 16). According to Arian (1985), power, and hence the historical course of Israeli society, lie within the formal political sphere, in the hands of the political elites.

This convention about the primacy of politics and 'decision makers' serves not only to separate the study of politics and economics, but also to divert attention from the class structure of Israel. Indeed, since control is in the hands of politicians 
and former army officers, and since these do not generally come from a capitalist background, it goes without saying that class conflict is irrelevant to the Israeli case. Israel, so it seems, is a classless society in which the process of capital accumulation, the growth and consolidation of a ruling class, the ownership of resources, the distribution of income, the control of economic power, the methods of persuasion and legitimation and the means of violence could all be safely ignored. Paradoxically, if there is any recognition of 'class struggle' in Israel, it is largely limited to the pre-Independence era- a period in which the society was hardly industrialized, in which there was barely any accumulation of capital or a meaningful working class, in which the most organized groups were the agricultural cooperatives, and in which the army and the police were those of a colonial power (Giladi 1973; Yatziv 1979). Since the 1970s, however, when these characteristics where long gone, replaced by a highly concentrated business structure, international economic integration, a developed industrial system of mass production and an urban amalgamation of wage earners - there is no single study about the Israeli ruling class or the process of accumulation, let alone the connection between them.

\section{THE 'Military BiAS'²}

An alternative assessment of Israeli history could begin from a theoretical framework linking the process of capitalist development and crisis with military spending, expansionary foreign policy and armed conflict. Early Marxist writers such as Hilferding (1910) and Luxemburg (1913), and institutionalists like Veblen (1904; 1923), saw the tendency toward economic and military expansionism as an outgrowth of the concentration of capital in the leading industrialized countries of their time. Later authors, such as Kalecki (1972), Tsuru (1961), Sweezy (1972) and Steindl (1976), claimed that a rising 'degree of monopoly' created a tendency for the societal surplus to rise while at the same time limiting the extent to which this surplus could be 'offset' by profitable investment outlets. The historical solution appeared in the form of 'military Keynesianism,' where a 'Keynesian coalition' between big business and organized labour administers rising 
military spending and a more aggressive foreign policy as a means of maintaining aggregate prosperity and high employment (Gold 1977). Other writers took a step further, suggesting that the militarization of the economy was driven not by the aggregate needs of employment and output, but rather by the profit requirements of the largest 'core' firms of the 'monopoly sector' (O'Connor 1973) or 'monopoly capital' (Baran and Sweezy 1966).

Conceptually, much of this research was concerned with the effect of economic structure on military spending. However, with continuous US involvement in South-East Asia it became increasingly clear that causality ran both ways and that military expenditures were in turn a factor of restructuring. One of the first to recognize this double-sided link was Kalecki $(1964 ; 1967)$, who predicted that the growing involvement of the US in Vietnam would shift the balance of power from the 'old' civilian industries in the east coast to the 'new' military-oriented groups in the west. Rising military budgets, he argued, would redistribute income in favour of the latter and fortify the 'angry elements' within the US ruling class, leading to what Melman (1985) later called a 'permanent war economy.'

It now appears that Kalecki was right, and that the war economy, which in the US lasted until the late 1980s, has indeed shifted the gravity centre of US business in favour of arms contractors. For the large US-based companies, the postwar international decline of the US economy spelled a predicament of excess capacity. This was partly counteracted by mergers and acquisitions, though the more pronounced response was a growing reliance on government budgetsparticularly in the area of military, space and medical technology. The consequence of this 'military bias' was a heightened process of differential accumulation in favour of the large arms contractors, who between the Vietnam War and the late 1980s saw their profit share in the big economy soaring (Nitzan, Rowley and Bichler 1989; Nitzan and Bichler 1995).

These considerations prove significant for the Israeli case in two ways. One is a striking structural similarity involving a direct link between military spending and market structure. The Marxist thesis of 'military Keynesianism' - that is, the counter-cyclical use of military spending to achieve macroeconomic goals_-may have been adequate for the 1950 s 
and 1960s when rising defense spending came together with overall economic expansion (Melman 1985). This thesis seems less robust, however, from the 1970s onward. Military procurement has become concentrated in a relatively small number of large companies, and as the dependency of these firms on military budgets increased, the flexibility of the US administration in manipulating these budgets tended to decline. (Indeed, the drop in military spending since the late 1980s would have been far more difficult to implement had it not been for the collapse of the Soviet Union and the rise of global investment outlets through NAFTA, GATT and the 'emergence' of Latin America and Asia.)

If we can generalize, it seems that under certain historical conditions, particularly in an early state of development or after a severe structural crisis, military expenditures can play a macroeconomic role, as argued by Benoit (1973) who described their effect on developing countries. But as the economy 'matures,' and the degree of concentration and centralization surpasses a certain threshold, military spending becomes less able in serving overall economic goals, and is catering more to the interest of dominant political and business groups. In this latter stage, the macroeconomic impact of such expenditures often become stagflationary (Smith 1977), but that is tolerated given their positive effect on the leading firms at the core (Griffin et al 1982). The Israeli economy, we argue, followed a similar historical pattern, with military spending initially associated with overall growth and subsequently accompanied by rising corporate concentration and heightened stagflation.

Second, beyond the structural similarities there is also a direct connection between the military bias in the two economies. Since the late 1960s, Israel was becoming increasingly integrated into the US orbit-a process which was partly a result of global expansion by US arms producers. During the period between the late 1960s and late 1970s, when US domestic military spending experienced a cyclical downturn, arms exports became increasingly crucial to the well being of the defense contractors-firstly as a stop-gap measure for falling orders at home, and secondly because of their higher profit margins. The most significant factor affecting the rise of arms exports was the global redistribution of income following the 1973 oil crisis. The explosive growth 
of oil revenues made the OPEC countries ideal clients for weaponry and, in 1974, after the US exist from Vietnam, the Middle East became the world's largest importer of weaponry.

The military bias of the Israeli economy coincided with this US foray into the armament market of the Middle East. Israel accepted its role as a US regional satellite, in return for massive military aid and US consent for economic protectionism. For the large US arms contractors, military sales to Israel quickly became part of a heightened arms race, which drew even larger clients such as Iran and Saudi Arabia into the cycle. For the large Israeli firms, the combination of a war economy and trade barrier proved equally beneficial, generating rising profit margins and a rapid surge in differential accumulation.

\section{MACROECONOMIC HISTORY IN STRUCTURAL RETROSPECT}

In assessing the parallels and interactions between the US and Israeli economies, it is instructive to begin with a bird-eye view of Israel's economic structure during the height of its militaristic phase. Our analysis follows the dual-economy approach which emphasises the firm rather than the industry (Steindl 1945; Edwards 1979; Bowring 1986). Furthermore, given our focus on differential accumulation, we look specifically at the distribution of profits rather than standard proxies such as sales or value added.

During the mid-1980s, the Israeli dual-economy was characterised by a 'big-economy' of about 50 firms, and a 'small economy' comprising the rest of the business sector and NGOs. The big economy consists of a core of five conglomerates-Leumi, Hapoalim, Israel Discount Bankholding (IDBH), Koor and Clal (the latter being controlled by the first three)—surrounded by a perimeter of somewhat smaller and far less diversified firms. The firms of the big economy dominate almost every significant business sector in Israel.

The history of the core conglomerates mirrors that of Israel. Bank Leumi was established in 1902 to finance Zionist colonial settlements. Bank Hapoalim was formed in 1921 to support cooperative activity in agriculture, construction and industry. IDBH began as a private bank in 1936, when capital 
flight from recession-hit Europe and British war preparations fuelled an economic boom in Palestine. Koor was established in 1944 as the industrial subsidiary of Solel Bonhe, after war spending had turned the latter into the largest contractor in the Middle East. Clal was set up in 1962 as a joint venture designed to lure foreign investment through tax incentives and subsidies, and eventually became a 'gravity centre' for the domestic core groups, the government and foreign investors.

Over time, cross ownership, kinship and cultural ties, procurement rights, credit arrangements and a complicated web of unwritten conventions and 'understandings' among the core groups, the lesser firms at the periphery of the big economy and the government, have given rise to an Israeli ruling class. (For a rare exposition of these arrangements, see Bejsky et al. 1986). Since the 1970s, the cohesion of this class has been reflected in converging business performance among the member companies of the big economy-particularly with regard to tax rates, subsidies, executive compensations and, most importantly, profits. ${ }^{3}$

In contrast to the big economy which in many respects acts like a single 'bloc,' the small economy is much more amenable to standard industrial analysis. Firms are small, usually operate in a single industry and often own a single plant; performance is subject to wide fluctuations with little or no inter-company correlation. Contrary to the big economy, 'business' is generally separate from 'politics,' with the link established only indirectly through loose professional associations and pressure groups.

The ramification of this duality, illustrated in Figure 1, was a heightened process of differential accumulation. The core groups of the big economy began their ascent already during the 1960s, but it was since the 1970s that their differential accumulation became patently clear: between the mid 1970s and mid 1980s, when stagflation, military spending and current account crises undermined the earnings in the 'small economy,' profits for the core groups soared. ${ }^{4}$

Such conflicting developments point to the shortcomings of macroeconomic and macropolitical analyses. When redistribution becomes systematic and overall outcomes consist of opposing underlying currents, the universal 'we' is not only insufficient, but actually misleading. A structural focus becomes imperative. 
Figure 1. Real Net Profits (1980 NIS, three-year moving average)

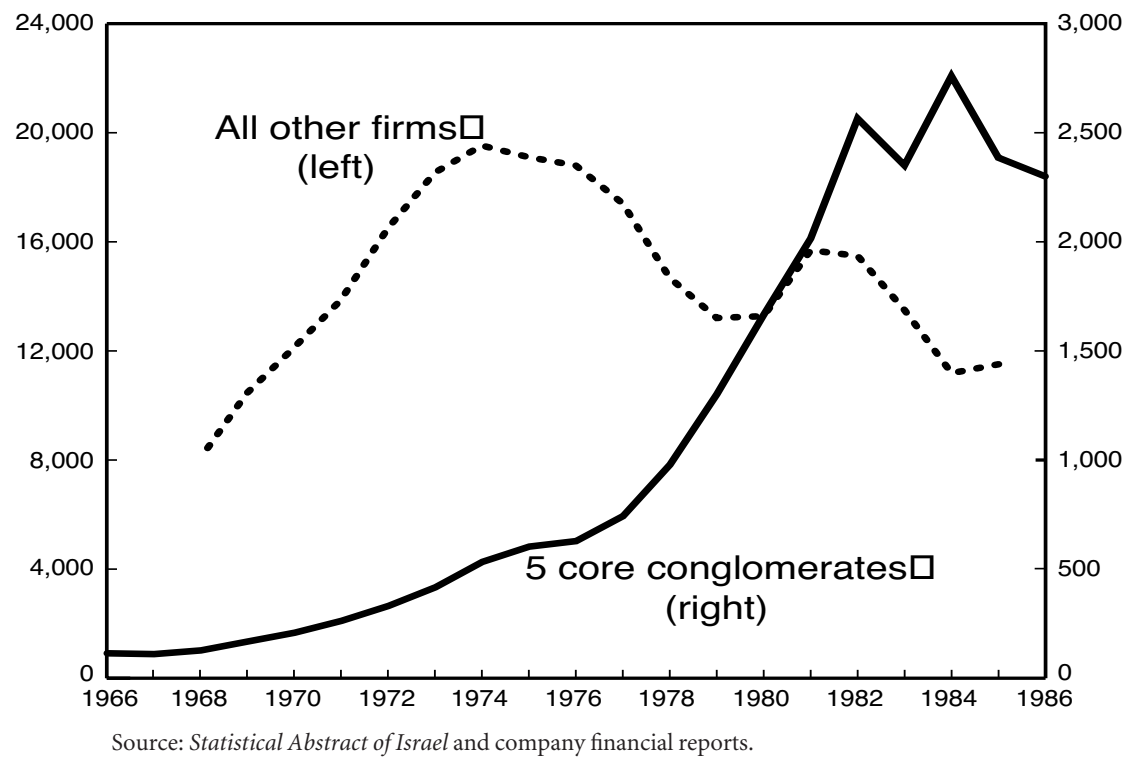

The interaction between macroeconomic development and differential accumulation in Israel could be perceived as belonging to three distinct 'regimes': (1) The period of 19551972, characterised by emphasis on the differential breadth of accumulation, with rapid macroeconomic growth and 'latent' structural consolidation, (2) the 1973-1984 era, in which the emphasis shifted to the differential breadth of accumulation accompanied by severe stagflation, and (3) the post-1985 era distinguished by retrenchment for the big economy, followed by a shift toward an open 'peace economy' and a return to the differential breadth of accumulation.

These broad contours are illustrated in Figure 2, (over page) where we contrast the economy's macroeconomic performance, indicated by GDP growth, with a proxy for differential accumulation, given by the ratio of the net profits of the five core conglomerates to GDP. Until 1972, the economy expanded at an average annual rate of 10 per cent, while differential accumulation by the core conglomerates was relatively contained below one half of one per cent. The 19731985 period was fundamentally different: there was a marked drop in overall growth rates, to an average of 3 per cent, and as 
Figure 2. Macroeconomic Growth and Differential Accumulation (Per cent, five-year moving average)

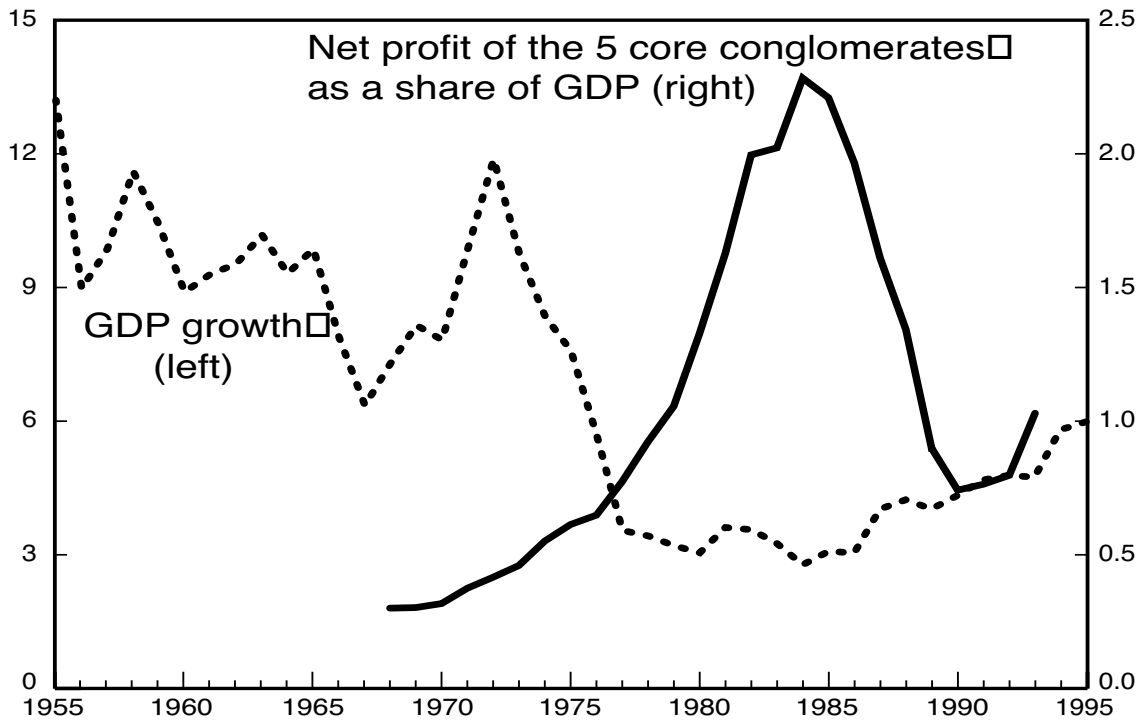

Source: Statistical Abstract of Israel and company financial reports.

stagnation lingered, the profit share of the core firms started to rise rapidly, climbing to a peak of nearly 2.3 per cent of GDP. From the mid-1980s onward, differential accumulation for the core firms turned negative and their profit share of GDP rapidly collapsed, reaching less than 0.75 per cent by 1990 . The political-economic shift since the late 1980s has contributed to revived overall growth, now accompanied by a parallel recovery for the core companies. In this section we deal with the first two regimes. The third phase is discussed in the fourth section.

Until 1972, economic growth in Israel was disproportionately affected by two 'external' stimuli: (1) the unilateral capital inflow of German compensation between 1955 and 1965, and (2) the 'Palestinians boom' in the immediate years after the 1967 War. During the 1955-1965 period, unilateral transfers from Germany accounted for most of the capital inflow, and were almost identical to the annual change in GNP. The end of these transfers in 1965 was followed by the severe recession of 1966-1967. The situation changed again in 1968, when the Israeli market suddenly expanded to include 
one million new consumers from the occupied territories of the West Bank and Gaza Strip. Furthermore, until 1973, fast increases in the number of Palestinian employees working in Israel augmented purchasing power. This combination of an overnight expansion of markets and a rapid process of proletarianization had a decisive multiplier effect on the Israeli economy. But, then, during the mid 1970s, when the growth in the number of Palestinians working in Israel started to decelerate, the economy reverted back to stagnation. ${ }^{5}$

These external impetuses acted to mitigate the latent process of aggregate concentration, primarily through their positive impact on the small economy. However, after 1974, with the growing differential accumulation by the big economy, the dynamics changed. The concentration process came into the open, accompanied by a fundamental political shift and the gradual decline of the government as a central economic force. The right-wing Likud bloc which assumed power in 1977, adopted an aggressive foreign policy and high military spending, while its 'liberal' economic agenda of laissez faire hastened the ascent of the core conglomerates.

The core conglomerates of today consolidated during the mixed-economy period after Independence. Until the early 1960s, investment was almost entirely financed by unilateral capital transfers and managed more or less exclusively by the government. The allocation of capital was determined partly by the government's import-substitution policies, but also by political and family ties. The government developed 'special relationships' with several rising business clusters which were originally considered as 'national agents' and eventually grew into the core groups of today (Patinkin 1963; Barkai 1964). These relationships started to shape immediately after Independence with the distribution of land and other properties belonging to the Palestinians who left during the war; it developed further during the 'Austerity' regime of the early 1950s which saw the allocation of exclusive certificates, monopolies, procurement rights and other forms of 'good will' to well-connected domestic and foreign groups; and it consolidated with the inflow of German compensation payments which financed a decade of growth between 1956 and 1965.

The Era of Rapid Growth and Structural Formation, 1955-1973 
The 1950s were a period of sharp contrasts. On the one hand, massive Jewish immigration from Europe, Asia and Africa more than doubled the population in just a few years. The immigrants were mainly impoverished refugees, with little marketable skills, often without knowledge of the language. Acute shortages arrested per capital growth, yet with the population expanding at over 9 per cent annually, overall economic activity was nonetheless booming. Given the economic dominance of the government, the business potential for politically-connected groups was huge. And indeed, by the early 1950s, only a few years after Independence, companies such as the Discount group have already grown 'too large' for the domestic market and began facing problems of excess capacity typical to mature economies (Recanati 1984: 71, 92-93).

The rapid expansion of public services and the acceleration of the Israeli-Arab conflict after the 1956 Suez War further accentuating the centrality of the government and boosted the significance of the military elites. Yet under the surface, these developments ushered a more fundamental process of corporate concentration. Foreign unilateral transfers and loans induced aggregate growth, but their allocation was highly unequal. During the 1950s and 1960s, growth was propelled more by government grants and subsidized loans than the 'animal spirits' of capitalists—-so much so, that for the leading businessmen at the receiving end accumulation often took place before production even started! This allocation system, known as the 'Sapir Method' after the finance minister at the time, encouraged binding institutional arrangements and centralization - though, for a while, its negative effect on economic growth was more than offset by the continuous flow of immigrants and foreign assistance. It was only since the early 1970s, when these external stimuli were no longer available, that the economy entered its monopolistic stage of 'militarized stagflation.'

Structural Change Since the early 1970s, economic activity was rapidly and the 'Military Bias,' 1974-1984 converging around two related poles-defense and finance. Earlier forays into military-related manufacturing were often explained by Israel's political isolation, though even then economic considerations were at least equally important. 
Initially, domestic production of weapons fitted nicely with the Labour government's import-substitution effort, while, later, military exports were seen as a possible solution to the country's chronic current-account deficit. Financial activity became increasingly significant, much like in other capitalist countries, as a consequence of a merger wave during the 1960s and early 1970s. At the centre of this process stood the wouldbe core conglomerates which started to form already during the 1950s from the amalgamation of small family banks and saving and loans cooperatives. ${ }^{6}$ Their expansion began in earnest, however, only during the 1965-66 recession, when the government's austerity policy triggered a massive wave of business consolidation. and stripped labour cooperatives of their remaining autonomy. ${ }^{7}$ Since the early 1970s, the government also started liquidating its direct industrial holdings, moving toward indirect intervention through subsidies and military contracts.

From the early 1970s onward, the growth of the large conglomerates came to depend increasingly on the differential depth rather than breadth of accumulation. This was achieved in three principal ways. First, mergers and acquisitions brought a larger share of the profit under the control of these firms, enabling them to better control competition and prevent an unruly rise in capacity. Second, with civilian production entering a period of protracted stagnation, resources started shifting into financial activity and inflation began to rise. The conglomerate's financial assets where inflated relative to the economy's total, and the share of labour eroded. Finally and perhaps most importantly, the intensification of the Israeli-Arab conflict contributed to rising military spending and growing arms exports. This burdened the aggregate economy, but much like in the US, the ensuing 'military bias' was highly beneficial, both relatively and absolutely, to the leading arms contractors of the big economy. Moreover, high tariff barriers, capital subsidies, grants and tax exemptions to support the militarized economy contributed further to the ascent of its large conglomerates.

This pattern of 'military/financial accumulation' was typical to all of the core firms. The Discount group (IDBH), for example, entered the military sector during the late 1960s. Through its subsidiary, Discount Investment Corporation, the company acquired numerous holdings in the military sector 
(usually in association with tax-exempt foreign partners), which within a few years began accounting for a rising share of IDBH's overall profits. The main outlet for these profits was the flourishing stock market, where IDBH-run mutual and pension funds were increasingly active in stock manipulation.

Much like IDBH, Koor too was enjoying the post-war prosperity. Riding the military multiplier and boosted by cheap credit from Bank Hapoalim, the group's labour force more than doubled to 22,000 in 1974, up from only 10,000 in 1967 , and net earnings soared. Operations were grouped into 13 'brigades' along military-bureaucratic principles. Top managerial position were staffed by retired army officers and financial decision were centralized. Although still nominally owned by its own workers (as well as by all other members of the Histadrut), the company was now behaving much like any other capitalist enterprise, with a rising ratio between executive compensation and factory-floor wages. Strategically, Koor concentrated on acquiring dozens of companies rendered vulnerable by the 1965-6 recession. The biggest incursion was into defense-particularly through Koor Trading which dealt with arms exports, and Tadiran which acted as a principal weapon producer.

The Clal group also began to grow along similar lines during the 1960s. After a few difficult years, the group was taken over by Bank Hapoalim, IDBH and others. From 1969 onward, Clal expanded via conglomerate mergers and acquisitions, financed largely with subsidized government loans (Aharoni 1976: 299). Most significantly, Clal has developed into the 'gravity centre' of the big economy - both by virtue of its ownership structure, as well as through a dense network of joint ventures with the other core conglomerates. Finally, much like the other groups, Clal too was becoming dependent on both military and finance. Notably, the growing 'military bias' of all of these groups was accompanied by the ascent of many retired IDF generals and chiefs of staff into their top managerial positions.

The interaction between military and finance in Israel was not incidental. The country's large military-related deficits were financed partly by grants and loans from the US, but mostly by a bulging domestic debt. The arrangement was doubly beneficial for the core conglomerates, who enjoyed the benefit of government indexed bonds on top of their thriving 
arms business. Capitalists often object to large government deficits on grounds that these serve to 'crowd out' private investment, though in the closed war economy of the 1970s and early 1980s, the large Israeli capitalists had little to lose from this arrangement. True, massive government borrowing contributed to three-digit real rates of interest, but these hardly hurt the core conglomerates. First, their virtual monopoly over credit helped them maintain the real spread between lending and borrowing rates at 20-50 per cent and, second, the effect on their profit of a high interest-rate regime was more then offset by political ties which assured cost-plus government contracts, subsidized loans and low taxes. Moreover, to the extent that monetized deficits contributed to inflation, their positive effect on profits and the value of financial assets far outweighed their impact on rising wages.

Despite these benefits, since the 1970s there was growing pressure for a greater 'liberalization' of capital markets. The goal, though, had little to do with improving 'allocative efficiency.' Indeed, when the government began reducing its directed loans, gross investment plummeted-falling to about 15 per cent of GDP in 1985, down from 30 per cent ten years earlier. The real reason behind the liberalization push was that the core conglomerates discovered a new gold mine-the stock market. Tight collusion, particularly among the large banks, enabled them to manipulate the price of their own shares-as well as those of many others-to the point of guaranteeing investors a predetermined real rate of return! In the words of the Bejsky Commission (Bejsky et al. 1986: 59), the banks were able to create a 'new type of security' combining the properties of shares and indexed bonds in the same paper. But in order to maximize the benefit of this invention, the government had to be pushed out and that required 'liberalization.'

The gradual withdrawal of the government gave rise to a 'parallel monetary policy' managed by the big banks: on the one hand, their systematic stock manipulation was tantamount to printing money, while on the other, the consequent market buoyancy enabled them to 'absorb' much of this newly created money by issuing new stocks. The consequence was a rapid inflationary redistribution of income. The principal winners where shareholders, particularly the banks themselves: they became the biggest owners of their own 
stocks whose value in 1982 reached 44 per cent of the economy's aggregate liquid assets, up from only 7 per cent in 1973 (Bejsky et al. 1986: 61).

The concentration process now emerged with all of its consequences. Since the 1970s, with the external stimuli of immigration, capital inflows and market expansion all gone, the focus of accumulation shifted from breadth to depth. By now, the economy had already accumulated a dense network of 'distributional coalitions' (to borrow Olson's terminology), whose interests lied in stagflation rather than growth and price stability. The process of corporate concentration and income redistribution undermined the political power of organized labour and restricted purchasing power. The economy began to suffer from 'excess capacity' - that is, an excess over what could be sold at profitable prices. For firms in the big economy, business success was thus increasingly dependent on limiting the growth of capacity and on using inflation to raise their share in the stagnating pie. And indeed, between 1973 and 1986, net investment dropped a full 76 per cent, while inflation rose to over 400 per cent in the mid 1980s, up from less than 20 per cent in the early 1970s (Statistical Abstract of Israel, various years). It was during this macroeconomic crisis that the large Israeli conglomerates experienced their fastest expansion (Figure 2).

In summary, since the 1970s, Israel was increasingly characterized by a dual-economy dominated by several large core conglomerates whose differential accumulation was sustained mainly through raising the depth of accumulation. The principal vehicles were armament and finance-the first supported by the accelerating Israeli-Arab conflict and the growing superpower involvement in the region, the latter by intensifying stagflation. The Israeli government was getting deeper into debt-with domestic debt services accrued principally to the big economy, and with foreign payments helping support the export drive of US-based military contractors. In the course of this process, Israel's power structure was radically transformed. The core conglomerates grew increasingly intertwined through a web of crossownership, business, political and kinship ties. The government, on the other hand, gradually lost its central role in the economy, moving from direct economic involvement, to indirect support and subsidization of the big economy, and 
eventually to passive mediation between the large domestic conglomerates, the leading American-based armament companies and the US Administration. The dominant-party system of the 1950s and 1960s had given way to a dominantcapital system.

But then the militarized order collapsed. Major weapon development projects were cancelled under US pressure, Israeli arms producers started losing money and the military industry-for years the celebrated 'crown jewel' of 'Israeli know-how' - suddenly turned into a 'burden.' The question is why? What made the military-business elite reverse its course? Why was the old order of war profits falling apart and what brought the new regime of 'peace dividends'?

\section{FROM WAR PROFITS TO PEACE DIVIDENDS: THE NEW ORDER}

Israel's transition into a new era of peace has been affected by several domestic and regional developments, but these must be understood within the broader transformation of global capitalism, particularly in the realm of ownership. Whereas until recently, globalization occurred mainly in the realm of production, the current phase extends globalization into the realm of ownership.

The globalization of ownership is intimately linked with a worldwide shift from the differential depth of accumulation to the differential breadth of accumulation. The main backdrop is the growing interaction between the developed and 'emerging' markets. For the local elites in the emerging markets, the first stage of transition often appears in the form of severe economic crisis and a threat to the institutions underlying the differential depth of accumulation. Thus, in Brazil, the debt crisis of the 1980s undermined the entreguista (collaborator) state; in India, the foreign exchange crisis of the early 1990s brought an end to the protectionism of the license raj'; in South Africa, the nose-dive of gold prices after 1980 put a seal on the 'labour shortage' rationale of apartheid; and in Israel, the collapse of the war economy and the bursting of the stock market bubble eliminated the main mechanisms of internal redistribution (Bichler and Nitzan 1996a; Nitzan 1996a). Following the crisis, the second stage is almost 
invariably associated with a fundamental rethinking of the link between capital and the state. With the ideological collapse of communism and Keynesianism, there is a growing recognition that the 'natural right of investment' - that is, the customary right to control a portion of the societal surplus-could no longer be secured solely by domestic legitimation, and must increasingly rely on global market power. The depth of accumulation declines in significance and the breadth of accumulation comes to the fore. The external manifestation of this process is the falling of trade barriers and the greater reliance on private investment flows.

For the local business groups, the initial effect often comes in the form of disintegrating institutional arrangements and a resulting collapse of their 'differential rate of return'. But this stage is usually short-lived, and is quickly compensated by privatization and deregulation, as well as by the opportunity to 'go global'. In South Africa, for instance, the large conglomerates are now willing to accept increasing domestic competition in return for the removal of capital controls and the ability to invest internationally (Nitzan 1996a). The situation of the Israeli core firms is not much different: foreign pressure forces them to divest locally and expand internationally, particularly into emerging markets in Asia, Latin America and Europe.

Renewed emphasis on the differential breadth of accumulation-a foregone conclusion among the leading multinational corporations for quite some time-is rapidly becoming an article of faith also in the periphery countries (Nitzan 1996b). The main consequence of this new consensus is the globalization of ownership-initially through crossborder corporate alliances, and subsequently through the diffusion of transnational ownership. In this sense, the current phase of globalization implies a higher stage of absentee ownership. Although the process is still dominated by westernbased firms, outward investment from developing countries is on the rise. Furthermore, with the growing significance of institutional investing, the nationality of owners becomes not only increasingly difficult to ascertain but also decreasingly relevant for the process of capitalization.

On the face of it, globalization seems to imply greater competition. Although global alliances are on the ascent and the large corporations continue to grow in size, this seems more than counteracted by the rapid decline of trade and 
investment barriers. Moreover, the opening of the world economy is accompanied by significant technological changes and macroeconomics growth. Large populations undergo a rapid process of proletarianization, which in turn enables the mushrooming of a vibrant small economy. The latter is also assisted by the high labour intensity of the information revolution, which reduces barriers to entry and enables fast growth with limited capital outlays.

One has to be careful, however, not to equate a growing small economy with rising 'competition.' The real test for the latter is the direction of differential accumulation-that is, the extent to which the rate of return of the world's largest firms surpasses the average. So far, there is little evidence that this differential has been undermined by globalization. In fact, 'freer' trade and investment may very well contribute toward faster differential accumulation. First, the growth of the small economy is at least partly a consequence of a more effective system of 'out-sourcing' by large corporations, which is in turn tantamount to the progressive 'absenteeism' of ownership: instead of extracting the surplus from its own subsidiaries, today's giant corporation operates more as a profit centre, appropriating the surplus via a long chain of small suppliers. The fact that the latter system is preferred to the former suggests it is indeed more profitable. Second, free trade makes it difficult to object to horizontal mergers and acquisitions, particularly cross-border ones. By the turn of the twenty first century, the consequence could well be the emergence of global dominant capital - this time, with little countervailing powers and no regulatory body. If that happens, differential accumulation may accelerate and the degree of global aggregate concentration may exceed current levels.

The shift of emphasis from depth to breadth in the process of differential accumulation, together with the consequent globalization of ownership carry significant political implications which cannot be analysed here. It seems clear, however, that one consequence is to heighten the conflict between McWorld and Jihad (Barber 1992) — that is, between the advent of democratic institutions and conciliatory foreign policy on the one hand, and a backlash of religious fundamentalism and xenophobic nationalism on the other. The move from a war economy to peaceful accumulation in Israel is part of this conflict. 
The Transition of The 1980s marked a severe economic crisis in Israel, with the Israel's Dominant differential depth of accumulation running into external and Capital: Crisis internal barriers. The principal cause was the demise of the Soviet Union and the changing political-economic arithmetic of the Middle East. The oil slump has pushed GDP per capita in the region's oil exporting countries down by as much as 3080 per cent relative to the hay days of the 1970s and early 1980s. At the same time, the populations of these countries have more than doubled (Nitzan 1996a: 13-15). The result has been an ongoing socio-economic crisis and growing political vulnerability. Western governments now see their main threat as Islamic fundamentalism, and with the old communist menace gone, their principal solution is a geo-political realignment.

The basis of this realignment is a pro-western axis extending from Turkey, through Syria, Lebanon, Jordan, Israel and Egypt (with possible outliers such as Morocco and Tunisia and even a future post-Hussain Iraq). This axis is expected to serve a number of purposes. Militarily, it will constitute an effective wedge in this hostile area and help protect stability in the Persian Gulf. Economically, this axis fits well into the 'emerging-markets' agenda of multinational corporations, and assuming the peace drive prevails, US-based companies are eager to secure their regional position vis à vis competitors from other countries. Politically, the hope is that lower trade and investment barriers will boost macroeconomic growth and that rising standards of living will then provide an alternative to the anti-western rhetoric of fundamentalist Islam.

This changing international framework has fatally undermined the Israeli war economy. Until the mid 1980s, US arms contractors and oil companies gained from Middle-East militarization (Nitzan and Bichler 1995). Israel, which received massive military assistance, was instrumental in maintaining regional tension, in assisting US arms exports, and in subversive activity around the world. In return, the 'deal' was for the US to let Israel maintain its own military industries (provided these did not undermine US arms shipments), as well as to allow it to keep a tightly oligopolistic market with high import and investment barriers. However, since the mid 1980s, world recession and a massive drop in the global demand for arms forced US-based producers to 
fight vigorously for contracts, so Israeli contractors had to give. The consequences was a decline in domestic military procurement as opposed to arms imports (which remained relatively stable), as well as a rapid collapse of Israeli arms exports (Nitzan 1994). In order to win export orders, Israeli weapon makers now find it necessary to team up as subcontractors with US companies. In parallel, since the $1990 / 91$ Gulf War, Israel is no longer seen as a western watchdog in the region, so US-based companies can now demand the opening of Israeli markets for imports and foreign investment. From this perspective, one could argue that the same US interests which earlier benefited from Israel's oligopolistic war economy are now promoting its transition toward an open peace economy.

For the Israeli core conglomerates, these external developments came on top of growing internal constraints. Until the mid-1980s, differential accumulation by these companies was supported by militarized stagflation which kept their profit margins way above the economy's average. However, like any system of redistribution, this too was limited by its own barriers. First, inflation threatened to throw fiscal management out of balance, and the stock market collapse of 1983 was a clear sign that monetary management too was getting out of hand. Second, persistent differential profitability for the big economy meant that the GDP share of military spending had to rise, which would eventually suffocate the economy. Moreover, given that local demand fell short of the necessary threshold for major weapon system development, arms exports could remain competitive only at the cost of heavy and rising subsidies.

Finally, the Palestinian Intifada (uprising) since 1987 was testing the dual-market relationship between Israel and the occupied territories. Until the mid 1980s, the West Bank and Gaza Strip were seen as political and business gold mines whose benefits in the form of cheap labour and captured markets far exceeded their 'maintenance cost.' However, with the collapse of oil prices, these costs began to mount. Lower income remittances from Palestinian workers in the Persian Gulf put growing pressures on a population already besieged by a rate of unemployment in excess of 50 per cent, mass seizure of land, administrative barriers and constant humiliation. The eventual backlash turned the territories into a net 
burden. Under these conditions, continued occupation threatened the very social fabric of Israeli society and the legitimacy of its so-called 'national consensus.'

The convergence of these forces coincided with an economic slump whose severity paralleled the recessions of 1965-66 and of the early 1970s. In contrasts to the previous downturns, however, the prospects for the core conglomerates now looked particularly dim. The earlier periods of stagnation were accompanied by a heightened military bias and accelerating inflation which contributed to the differential depth of accumulation by the core groups and augmented the aggregate concentration of profit (Figure 2); this time, neither military spending nor inflation were viable options. A change of regime seemed imminent.

The Transition of And, indeed, much like in the aftermath of the South-African, Israel's Dominant Indian, or Brazilian crises, the Israeli business elite, too, has Capital: Globalization realized that the old order had finally reached its limit. The new path was fairly clear. The Israeli conglomerates now had to focus on expanding their differential breadth of accumulation, which implied an end to the war economy, liberalization, 'flexible' labour markets, lower trade barriers and capital decontrols. None of this could be sustained without peace, and so from 1990 onward, the core conglomerates grew increasingly vocal in their support of regional reconciliation. ${ }^{8}$

The implications are twofold. First, removing the Arab boycott and creating a perception of a stable regional environment enable Israeli companies to expand business connections outside the region. The Middle-East itself offers future potential for Israeli firms, but the immediate gains are limited: GDP per capita in most neighbouring countries is very low, there is little overlap between the Arab demand profile and Israeli production lines, and suspicion and hostility still linger (Sagi and Sheinin 1994). The main promise lies outside the region, particularly in the emerging markets, and the effects are already evident in the data: as Figure 3 illustrates, the progressive maturation of Israeli exports has been recently broken by a rapid foray into the previously closed emerging markets. 
Figure 3. Average Annual Growth Rate (\%) of Israeli Exports (in US\$)

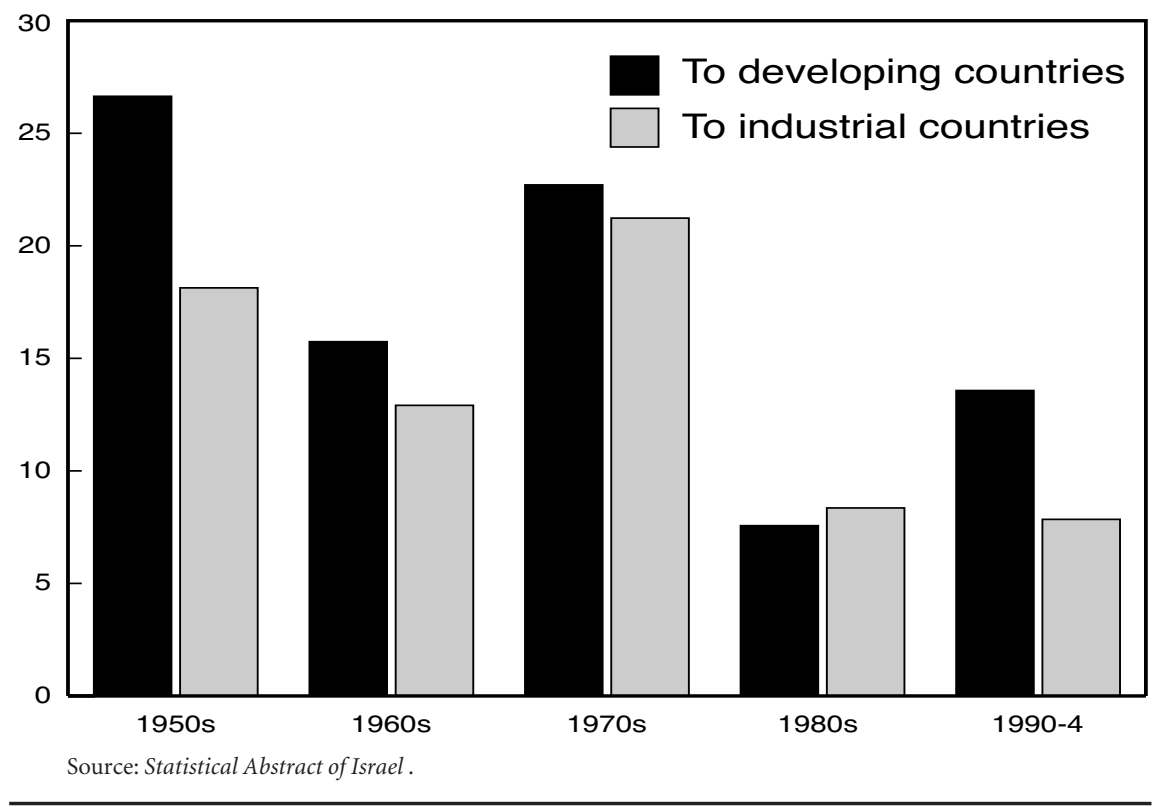

Second, the process of outward expansion is intimately related to the changing ownership structure of the core conglomerates. Over the past several years, direct foreign investment in Israel (as well as of Israeli companies abroad) has been rising rapidly (Figure 4, over page). The nature and extent of this investment marks a sharp departure from past experience. Whereas earlier, foreign investors had to be attracted by large grants and generous tax exemptions in order to compensate for Israel's high country risk, the current trend is driven by a desire to establish regional footholds in preparation for Middle East development. Companies which have never before operated in Israel, such as Volkswagen, Nèstle, Citicorp, Cable and Wireless, Shamrock, Enron, Bechtel, Toyota and many others, are now teaming up with the Israeli conglomerates.

This process coincides with growing pressure on the core conglomerates to divest some of their extensive holdings. In addition, the largest three banks-Hapoalim, Leumi and Discount-which have been under government control since the stock market crash of 1983, are up for re-privatization. 


\section{Figure 4. Foreign Direct Investment (US\$ millions)}

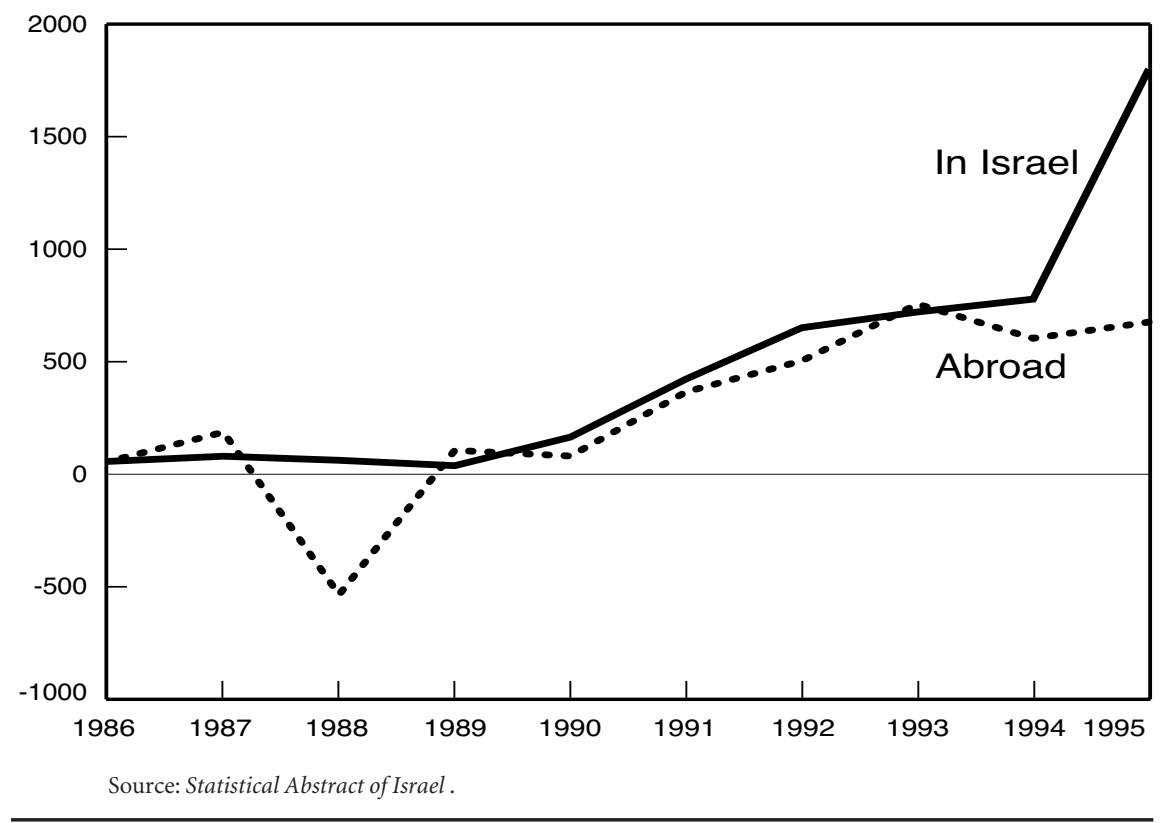

Officially, divestment and privatization are sanctioned in the name of 'competition' and 'efficiency,' but this merely serves to conceal the changing nature of absentee ownership. Much like in South Africa, the 'attack' on big business is at least partly driven by pressure from the Untied States and Europe to open the Israeli market to foreign investment. But like in South Africa, the Israeli business elite too is set to benefit from the ensuing restructuring. The rigid cross-ownership structure of the core conglomerates was adequate for the earlier regime of a closed militarized economy. The emphasis was on the differential depth of accumulation by maintaining aboveaverage profit margins. This necessitated an intricate system of mutual 'understandings' and institutional arrangements which were facilitated by cross-ownership and multiple holdings. The end of this regime, however, eliminated some of the need for close coordination, and reduced the need for conglomerate structures. Direct investment is no longer the only means of controlling the flow of profit, which is now often done more effectively and with far greater flexibility through portfolio stock ownership. 
These conjectures suggest that we should be careful not to misinterpret the apparent decline of the core conglomerates. On the face of it, the pending dismembering of these companies, the entry of foreign investors and the rise of smaller groups seem to imply that the Israeli economy is entering a period of falling concentration and greater competition. Such conclusions may prove too hasty for two principal reasons. First, with Israeli outward investment on the rise, differential accumulation will increasingly depend on the company's global position and international ownership ties. On these counts, the core groups are already far ahead of their smaller counterparts, and their differential pace of outward expansion suggests the gap will only widen. Second, with mergers and acquisitions becoming more commonplace and frequent, our existing definition of Israel's dominant capital may prove too rigid. As the pattern of ownership grows more fluid and unstable, it may be necessary to go beyond corporate entities and identify the holdings of key individuals. Such data may be hard to collate, but the evidence they shall provide will be well worth the effort.

\section{EPILOGUE}

The elections of May 1996 seems to have re-shuffled the political cards, with the new government, led by the right-wing Likud bloc, apparently set to slow down the peace process. Yet, the parameters underlying the current trajectory of capital accumulation remain unaltered. In the absence of outward investment and export growth, the core conglomerates will see their profits plummet and the euphoria of foreign investor will quickly turn into gloom. With investment already at a very high proportion to GDP, reneging on the peace process will likely send the economy into a tailspin. As these lines are written, there are mounting pressures on Netanyahu-from the US administration and Europe, as well as from the large domestic companies and foreign investors-to follow the footsteps of the Rabin/Peres government. In this context, the Likud's loyalty to the 'Washington Consensus' of free markets and sound finance makes it difficult to simultaneously fulfil its dream of a 'greater Israel'. 


\section{Notes}

\section{References}

Aharoni, Y. (1969) 'Institutional Rigidity and Resource Utilization,' (in Hebrew), Economic Quarterly, Vol.16, No.62, July: 157-168.

(1976) Structure and Performance in the Israeli Economy, (in Hebrew), Cherikover, Tel Aviv.

(1991) The Political Economy of Israel, (in Hebrew), Am Oved and The Levi Eshkol Institute, Tel Aviv.

Arian, A. (1985) Politics and Government in Israel, (in Hebrew), ZmoraBitan, Tel Aviv..

(1989) Politics in Israel: The Second Generation, 2nd Ed. Chatham House, Chatham, N.J.

Baran, P. and P.M. Sweezy (1966) Monopoly Capital. An Essay on the American Economic and Social Order, Modern Reader Paperback, New York \& London. 
Barber, B.R. (1992) 'Jihad Vs. McWorld,' The Atlantic, March: 53-55, 58-63.

Barkai, H. (1964) 'The Public Sector, Histadrut Sector and Private Sector in the Israeli Economy,' Sixth Report, 1961-63, The Maurice Falk Institute of Economic Research, Jerusalem.

Barnet, R.J. (1972) Roots of War. The Men and Institutions Behind U.S. Foreign Policy, Atheneum Publishers, New York.

Barnett, M.N. (1992) Confronting the Costs of War. Military Power, State, and Society in Egypt and Israel, Princeton University Press, Princeton, N.J.

Bejsky, M., V. Ziller, Z. Hirsh, Z. Sarnat and D. Friedman (1986) Report of the Commission of Inquiry Into the Manipulation of the Banking Shares, (in Hebrew), Government Printer, Jerusalem.

Benoit, E. (1973) Defense and Economic Growth in Developing Countries. Lexington Books, Lexington, Mass.

Ben Dor, G. (1977) 'Politics and Military in Israel in the Seventies,' (in Hebrew), in M. Lissak and E. Gutmann (eds.) The Israeli Political System, Am Oved, Tel Aviv: 411-32.

Berglas, E. (1970) 'Defense, Standard of Living and Foreign Debt,' (in Hebrew), Economic Quarterly, Vol.17, No.67, September: 191-202.

(1983) 'Defense and the Economy: The Israeli Experience,' Discussion Paper 83.01, The Maurice Falk Institute of Economic Research, Jerusalem.

Bichler, S. (1991) The Political Economy of Military Spending in Israel, (in Hebrew), Unpublished Doctoral Dissertation, Department of Political Science, Hebrew University, Jerusalem.

Bichler, S., R. Rowley and J. Nitzan (1989) 'The Armadollar-Petrodollar Coalition: Demise or New Order?' Working Paper 11/89, Dept. of Economics, McGill University, Montreal.

Bichler, S. and J. Nitzan (1996a) 'Military Spending and Differential Accumulation: A New Approach to the Political Economy of Armament -The Case of Israel,' Review of Radical Political Economics, Vol.28, No.1: 52-97.

(1996b) 'Putting the State in its Place: US Foreign Policy and Differential Capital Accumulation in Middle-East "Energy Conflicts,"” Review of International Political Economy, forthcoming.

Bowring, J. (1986) Competition in a Dual Economy, Princeton University Press, Princeton.

Edwards, R. (1979) Contested Terrain. The Transformation of the Workplace in the Twentieth Century, Basic Books, New York.

Farjoun, E. (1978) 'The Palestinian Workers-An Economic Reserve Army,' (in Hebrew), Red Papers, No.5, Jerusalem.

(1980) 'Palestinian Workers in Israel-A Reserve Army of Labour,' Khamsin, No.7: 107-143, London.

(1983) 'Class Division in Israeli Society,' Khamsin, No.10: 29-39, London.

Frenkel, S. and S. Bichler (1984) The Rich Families, (in Hebrew), Kadim, Tel Aviv.

Giladi, D. (1973) The Yeshuv During the Fourth Migration 1924-1929. An Economic and Political Examination, (in Hebrew), Am Oved, Tel Aviv. 
Gold, D.A. (1977) 'The Rise and Decline of the Keynesian Coalition,' Working Papers on the Kapitalistate, Vol.6: 129-61.

Goldberg, G. (1992) Political Parties in Israel_From Mass Parties to Electoral Parties, Ramot-Tel Aviv University, Tel Aviv.

Griffin, J.L., J.A. Devine and M. Wallace (1982) 'Monopoly Capital, Organized Labor, and Military Expenditures in the United States, 19491976,' in M. Burawoy and T. Skocpol (eds.) Marxist Inquiries: Studies of Labor, Class and States, American Journal of Sociology, Vol.88, Supplement.

Hakeynee, R. (1994) 'The Political Process and the Elites: Statements by the Elites Regarding the Peace Process from the mid-1980s until the Declaration of Principles (September 1993)', (in Hebrew), mimeograph, Hebrew University, Jerusalem.

Halevi, N. and R. Klinov-Malul (1968) The Economic Development of Israel, Praeger, New York \& Jerusalem.

Hasid, N. and O. Lesser (1981) 'Economic Resources for Israel's Security,' (in Hebrew), Economic Quarterly, Vol.28, No.109: 243-252.

Hilferding, R. (1910; 1981) Finance Capital. A Study of the Latest Phase of Capitalist Development, Edited with an introduction by T. Bottomore, from trans. by M. Watnick and S. Gordon, Routledge \& Kegan Paul, London.

Horowitz, D. (1982) 'The Israel Defense Forces: A Civilianized Military in a Partially Militarized Society,' in R. Kolkowitz and A. Korbonski (eds.) Soldiers, Peasants and Bureaucrats, George Allen \& Unwin, London: 77-106.

Horowitz, D. and M. Lissak (1988) 'Democracy and National Security in a Continuous Conflict,' (in Hebrew), Yahadoot Zemanenu, Vol.4: 27-65.

(1989) Trouble in Utopia: the Overburdened Polity of Israel, State University of New York Press, Albany, N.Y.

Israel, Central Bureau of Statistics (various years) Statistical Abstract of Israel. Jerusalem.

Kalecki, M. (1964) 'The Fascism of Our Times.' Reprinted in M. Kalecki (1972): 99-106.

(1967) 'Vietnam and U.S. Big Business.' Reprinted in M. Kalecki (1972): 107-114.

(1972) The Last Phase in the Transformation of Capitalism, Monthly Review Press, New York.

Klieman, A. (1992) Double-Edged Sword. Israel Defense Exports as an Instrument of Foreign Policy, (in Hebrew), Am Oved, Tel Aviv.

Krasner, S.D. (1978) Defending the National Interest, Princeton University Press, Princeton, N.J.

Luxembourg, R. (1913; 1951) The Accumulation of Capital, Trans. from the German by A. Schwarzschild, with an introduction by J. Robinson, Monthly Review Press, New York.

Melman, S. (1985) The Permanent War Economy. American Capitalism in Decline, Revised and Updated, Simon \& Schuster, New York.

Migdal, J.S. (1989) 'The Crystallization of the State and the Struggles Over Rulemaking: Israel in Comparative Perspective,' in B. Kimmerling (ed.) The Israeli State and Society. Boundaries and Frontiers, State University of New York Press, Albany, N.Y.: 1-27. 
Mintz, A. (1984) 'The Military-Industrial Complex: The Israeli Case,' in M. Lissak (ed.) Israeli Society and its Defense Establishment, Frank Cass, London: 103-27.

Nitzan, J. (1992) Inflation as Restructuring: A Theoretical and Empirical Account of the US Experience, Unpublished Doctoral Dissertation, Department of Economics, McGill University, Montreal.

(1994) 'The Israeli Defense Industry: A Peace Dividend for Stock Pickers?' Emerging Markets Analyst, Vol.3, Issue 1: 8-9.

(1996a) 'Israel and South Africa: Prospects for Their Transitions,' Emerging Markets Analyst, Vol.4, Issue 10: 12-18.

(1996b) 'US-Based Transnational Corporations and Emerging Markets,' in Emerging Markets Analyst, Vol.5, Issue 3: 12-24.

Nitzan, J. and S. Bichler (1995) 'Bringing Capital Accumulation Back In: The Weapondollar-Petrodollar Coalition-Military Contractors, Oil Companies and Middle-East "Energy Conflicts," Review of International Political Economy, Vol.2, No.3: 446-515.

Nitzan, J., R. Rowley and S. Bichler (1989) 'Changing Fortunes: Armaments and the U.S. Economy,' Working Paper 8/89, Department of Economics, McGill University, Montreal.

O'Connor, J. (1973) The Fiscal Crisis of the State, St. Martin's Press, New York.

Patinkin, D. (1965) The Israeli Economy in The First Decade, (in Hebrew). Jerusalem: Maurice Falk Institution for Economic Research.

Peri, Y. (1983) Between Battles and Ballots: Israeli Military in Politics, Cambridge University Press, Cambridge.

Recanati, H. (1984) Recanati, Father and Son, (in Hebrew), Kenne, Jerusalem.

Robinson, J. (1962) Economic Philosophy, Penguin, Harmondsworth, England.

Rowley, R., S. Bichler and J. Nitzan (1988) 'Some Aspects of Aggregate Concentration in the Israeli Economy, 1964-1986,' Working Paper 7/88, Department of Economics, McGill University, Montreal.

Rowley, R., S. Bichler and J. Nitzan (1989) 'The Armadollar-Petrodollar Coalition and the Middle East,' Working Paper 10/89, Department of Economics, McGill University, Montreal.

Sadan, E. (1985) 'National Security and National Economy,' (in Hebrew), in Z. Lanir (ed.) Israeli Security Planning in the 1980s. Its Politics and Economics, Tel Aviv University, The Jaffee Centre for Strategic Studies, Ministry of Defense, Tel Aviv : 119-29.

Sagi, E. and Y. Sheinin (1994) 'Opportunities For Trade With Arab Countries,' (in Hebrew), The Economic Quarterly, Vol.41, No.1, April: 15-27.

Shapiro, Y. (1975) The Organization of Power, (in Hebrew), Am Oved, Tel Aviv. (1977) The Democracy in Israel, (in Hebrew), Massada, Ramat Gan.

(1984) An Elite Without Successors. Generations of Political Leaders in Israel, (in Hebrew), Sifriat Poalim, Tel Aviv.

Sharkansky, I. (1987) The Political Economy of Israel, Transaction Books, New Brunswick, N.J.

Skocpol, T. (1985) 'Bringing the State Back In: Strategies of Analysis in Current Research,' in P.B. Evans, D. Rueschemayer and T. Skocpol (eds.) Bringing The State Back In, Cambridge University Press, Cambridge: 3-37. 
Smith, R.P. (1977) 'Military Expenditure and Capitalism,' Cambridge Journal of Economics, Vol.1, No.1, March: 61-67.

Steindl, J. (1945) Small and Big Business, Basil Blackwell, Oxford.

(1976) Maturity and Stagnation in American Capitalism, Monthly Review Press, New York \& London.

Sweezy, P.M. (1972) Modern Capitalism and Other Essays, Monthly Review Press, New York.

Tilly, C. (ed.) (1975) The Formation of National States in Western Europe, Princeton University Press, Princeton, N.J.

Tsuru, S. (1961) 'Has Capitalism Changed?' in S. Tsuru (ed.) Has Capitalism Changed? An International Symposium on the Nature of Contemporary Capitalism, Iwanami Shoten, Tokyo.

(1968) 'Keynes versus Marx: The Methodology of Aggregates,' in D. Horowitz (ed.) Marx and Modern Economics, Modern Reader Paperbacks, New York \& London: 176-202.

Tuma, E.H. et al. (1989) 'The Economies of Israel and the Occupied Territories: War and Peace-A Panel Discussion,' (in Hebrew), Economic Quarterly, No.139: 593-606.

Veblen, T. (1904; 1975) The Theory of Business Enterprise, Augustus M. Kelley, Clifton, N.J.

(1923; 1967) Absentee Ownership and Business Enterprise in Recent Times. The Case of America, Beacon Press, Boston.

Yatziv, G. (1979) The Class Basis for Party Association - The Example of Israel, (in Hebrew), Research in Sociology, Department of Sociology, Hebrew University, Jerusalem. 